\title{
鉄筋コンクリート部材の塑性変形能定量化に関する研究
}

\section{EVALUATION OF THE DUCTILITY OF REINFORCED CONCRETE MEMBERS}

\author{
町田篤彦*・睦好宏史 ${ }^{* *}$ ・豊田和彦*** \\ By Atsuhiko MACHIDA, Hiroshi MUTSUYOSHI and Kazuhiko TOYODA
}

\begin{abstract}
Cyclic loading tests were carried out using cantilever type reinforced concrete beams, in order to obtain a reliable equation to estimate the ductility which is one of the most important properties in earthquake resistant design. The factors adopted were main reinforcement ratio, web reinforcement ratio, $a / d$, axial compressive stress, compressive strength of concrete, number of repetitions of loading, maximum size of coarse aggregate and so on. The effects of these factors on the ductility were investigated one by one. The results were summarized to a series of equations to estimate the ductility as a term of ductility factor. It was proved that the derived equations can essentially evaluate the effects of the factors on the ductility and can estimate the ductility factor with satisfactory accuracy, even a little modification may be needed on the effect of the maximum size of coarse aggregate and the effect of longitudinal reinforcements arranged along the side faces.

Keywords : reinforced concrete member, earthquake resistant design, evaluation of ductility, ductility factor
\end{abstract}

\section{1. 序論}

鉄筋コンクリート構造物の耐震設計法に関しては,「生 ずる可能性がある最大規模の地震に対しては, 崩壊は防 ぐが，ある程度の塑性変形は許容する」という設計法が 合理的であることには異論がなく，現行のいずれの設計 基準も, 塑性変形が生ずることをなんらかの形で考虑に 入れている.このような設計法の最も直接的な形式は, 地震により生ずる部材断面力と耐力を比較するととも に, 各部材の応答変形量と終局変形能を比較することに よって安全度を検討するというものであろう.しかし， 現行のいずれの設計基準でも, このような直接的な形式 は採用していない。これは，正負交番載荷を受ける場合 の部材の塑性変形能（いわゆる勒性）を精度よく算定す る方式が確立されていないからである.

正負交番荷重下の鉄筋コンクリート部材の塑性変形能 を定量化しようとする試みは, もちろん，すでに何人か の研究者によってなされている.すすわち, 荒川ら尚お よび島津 ${ }^{21}$ は, 建築構造物を対象として, 鉄筋コンクリー 卜部材の塑性変形能を算定する方法を提案しているし,

$*$ 正会員 工博 埼玉大学教授 工学部建設工学科 (

** 正会員 工博 埼玉大学助手 工学部建設工学科 (同上)

*** 正会員 工修 フジタ工業
檜貝ら ${ }^{3)}$, 石橋ら ${ }^{4)}$ おび著者ら ${ }^{5), 6)}$ は, 土木構造物を対 象として, 同様の提案を行っている. しかし, 建築構造 物においては, 鉄筋量, せん断スパン比, 軸圧縮応力な ぞ, 塑性変形能に重要な影響を及ぼす要因が土木構造物 と大きく相違しているので, 建築構造物を対象とした荒 川らおよび島津の成果は, 土木構造物に対しては適用す ることはできないと考えられる. また, 檜貝ら, 石橋ら, 著者らの成果は土木構造物を対象としたものであるが, いずれも精度が十分とはいいがたく，実際に鉄筋コンク リート構造物の耐震設計に適用できる域に到達していな い.この理由は, 部材の終局状態を支配する部分と変位 を測定する部分が同じでないという問題点, 塑性変形能 に及ぼす諸要因の影響を曲げ耐力に対するせん断耐力の 比 (以下, 単に, 耐力比という) という形で, 包括的に 捉えているという問題点などに求めることができると考 えられる.これらの問題点に対してもある程度の対処が 試みられてはいるが, 完全に解決されるには至っていな い.

本研究は,このような状況に対処するために行ったも のであって, 土木構造物における鉄筋コンクリート部材 を対象とし, これについて, 塑性変形を許容する耐震設 計法で用い得るような精度を有する塑性変形能算定式を 得ようとして行ったものである. すなわち, まず, 塑性 
変形能に影響を及ぼす要因の 1 つ 1 つを独立に変化させ た供試体について正負交番載荷実験を行い，ひびわれ性 状, 変形性状, 破壊性状等を詳細に検討した。ついで, この結果に基づき，上記のような既往の研究の問題点に ついて検討を加え, これらの要因のおのおのと塑性変形 能の関係を定式化したうえ，これらを合わせて本研究で 採用したすべての要因の影響を含む塑性変形能算定式を 得た。そして，既往の実験データによってその精度を検 討したのである.

\section{2. 実験方法}

\section{（1）供試 体}

図一 1 に示すような形状の供試体を用いて正負交番載 荷実験を行った。実験要因として, 引張鉄筋比 $\left(p_{t}\right)$, 帯鉄筋比 $\left(p_{w}\right)$, コンクリート強度 $\left(f_{c}^{\prime}\right)$, 女ん断スパ ン比 $(a / d)$, 軸圧縮応力度 $\left(\sigma_{0}\right)$, 粗骨材の最大寸法 $\left(G_{\max }\right)$, 載荷繰返し回数 $(n)$ の合計 7 個を選択した. 供試体は, これらの 7 要因を,一般的な土木構造物で想 定される範囲をカバーするように変化させて製作したの であって, $p_{t}=0.59 \sim 1.66 \%, p_{w}=0 \sim 0.24 \%, a / d$ $=2.5 \sim 6.0, \quad \sigma_{0}=0 \sim 30 \mathrm{~kg} / \mathrm{cm}^{2}, \quad f_{c}^{\prime}=128 \sim 565 \mathrm{~kg} / \mathrm{cm}^{2}$, $G_{\max }=5 \sim 25 \mathrm{~mm}, n=1 \sim 30$ 回とした. 実験に用いたす べての供試体の諸元を表一 1 に示す。また，用いた鉄筋 の機械的性質を表一2に示す.

\section{（2）載荷方法ならびに計測方法}

載荷装置および供試体の固定方法の概略を図一2に示 す. 同図のように，片持ちばり型の供試体を水平にして

表一1 供試体諸元およびひびわれパターン

\begin{tabular}{|c|c|c|c|c|c|c|c|c|c|c|}
\hline $\begin{array}{ll}\mathrm{Na} \\
\end{array}$ & \begin{tabular}{|l|}
$P(t)$ \\
$(\%)$
\end{tabular} & $\begin{array}{l}P_{w} \\
(\%)\end{array}$ & $a / d$ & $\left.\begin{array}{c}\sigma 0 \\
\left(\mathrm{~kg} / \mathrm{cm}^{2}\right)\end{array}\right)$ & $\underset{\left(\mathrm{hg} / \mathrm{cm}^{\prime}\right)}{\mathrm{f} \mathrm{c}^{\prime}}$ & $\underset{\substack{\max \\
(m)}}{m}$ & $\begin{array}{c}n \\
\text { (cycles) }\end{array}$ & $\mu_{\mathrm{ut}}$ & $\mathrm{V} \cdot \mathrm{a} / \mathrm{M}$ & 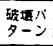 \\
\hline \begin{tabular}{|l|}
5 \\
13 \\
\end{tabular} & 1.06 & 0.12 & 4.00 & 0 & $\begin{array}{l}203 \\
279 \\
\end{array}$ & 12.5 & 10 & $\begin{array}{l}5.5 \\
4.7 \\
\end{array}$ & $\begin{array}{l}1.38 \\
1.43 \\
\end{array}$ & $\begin{array}{l}2 \\
2\end{array}$ \\
\hline \begin{tabular}{|l|}
4 \\
3 \\
9 \\
\end{tabular} & \begin{tabular}{|l}
0.59 \\
0.89 \\
1.66
\end{tabular} & 0.12 & 4.00 & 0 & $\begin{array}{l}406 \\
357 \\
338\end{array}$ & 12.5 & 10 & $\begin{array}{r}27.1 \\
7.1 \\
3.9\end{array}$ & $\begin{array}{l}2.19 \\
1.71 \\
1.22 \\
\end{array}$ & $\begin{array}{l}2 \\
2\end{array}$ \\
\hline $\begin{array}{l}8 \\
7 \\
6 \\
\end{array}$ & 1.06 & $\begin{array}{l}0.00 \\
0.08 \\
0.23 \\
\end{array}$ & 4.00 & 0 & $\begin{array}{l}413 \\
400 \\
318 \\
\end{array}$ & 12.5 & 10 & $\begin{array}{l}3.6 \\
4.9 \\
7.5 \\
\end{array}$ & $\begin{array}{l}1.18 \\
1.37 \\
1.76\end{array}$ & $\begin{array}{l}3 \\
2 \\
1\end{array}$ \\
\hline \begin{tabular}{|l|}
2 \\
11 \\
12 \\
\end{tabular} & 1.06 & 0.12 & $\begin{array}{l}3.00 \\
5.00 \\
6.00 \\
\end{array}$ & 0 & $\begin{array}{l}309 \\
389 \\
363 \\
\end{array}$ & 12.5 & 10 & $\begin{array}{r}3.8 \\
6.5 \\
34.3 \\
\end{array}$ & $\begin{array}{l}1.17 \\
1.75 \\
2.01 \\
\end{array}$ & $\begin{array}{l}2 \\
1 \\
\end{array}$ \\
\hline \begin{tabular}{|l|}
14 \\
15 \\
\end{tabular} & 1.06 & 0.12 & 4.00 & $\begin{array}{l}10 \\
20 \\
\end{array}$ & $\begin{array}{l}294 \\
301 \\
\end{array}$ & 12.5 & 10 & $\begin{array}{l}4.0 \\
3.4 \\
\end{array}$ & $\begin{array}{l}1.31 \\
1.21 \\
\end{array}$ & $\begin{array}{l}2 \\
2 \\
\end{array}$ \\
\hline \begin{tabular}{|l|}
1 \\
10 \\
16 \\
\end{tabular} & \begin{tabular}{|l}
0.89 \\
0.66 \\
1.06 \\
\end{tabular} & 0.12 & $\begin{array}{l}3.00 \\
5.00 \\
3.00 \\
\end{array}$ & $\begin{array}{c}0 \\
0 \\
10 \\
\end{array}$ & $\begin{array}{l}330 \\
376 \\
307 \\
\end{array}$ & 12.5 & 10 & $\begin{array}{l}6.5 \\
4.2 \\
3.5 \\
\end{array}$ & $\begin{array}{l}1.39 \\
1.47 \\
1.07 \\
\end{array}$ & $\begin{array}{l}2 \\
2 \\
3 \\
\end{array}$ \\
\hline 19 & 0.99 & 0.12 & 4.00 & 10 & 330 & 12.5 & 10 & 4.5 & 1.41 & 1 \\
\hline \begin{tabular}{|l|}
17 \\
18 \\
20 \\
21 \\
\end{tabular} & 0.99 & 0.12 & 4.00 & $\begin{array}{r}0 \\
5 \\
20 \\
30 \\
\end{array}$ & $\begin{array}{r}308 \\
298 \\
321 \\
326 \\
\end{array}$ & 12.5 & 10 & $\begin{array}{l}5.6 \\
5.8 \\
4.3 \\
4.2 \\
\end{array}$ & $\begin{array}{l}1.55 \\
1.46 \\
1.28 \\
1.19 \\
\end{array}$ & $\begin{array}{l}1 \\
1 \\
1 \\
3 \\
\end{array}$ \\
\hline \begin{tabular}{|l|}
22 \\
23 \\
\end{tabular} & \begin{tabular}{|l|l} 
& 0.99
\end{tabular} & 0.12 & 4.00 & 10 & $\begin{array}{l}335 \\
254\end{array}$ & $\begin{array}{r}5.0 \\
25.0 \\
\end{array}$ & 10 & 4.0 & $\begin{array}{l}1.42 \\
1.36\end{array}$ & $\frac{2}{2}$ \\
\hline \begin{tabular}{|l|}
24 \\
28 \\
\end{tabular} & \begin{tabular}{|l|l} 
& 0.99
\end{tabular} & 0.12 & 4.00 & 10 & $\begin{array}{l}565 \\
140 \\
\end{array}$ & 12.5 & 10 & $\begin{array}{l}4.3 \\
5.1 \\
\end{array}$ & $\begin{array}{l}1.53 \\
1.22 \\
\end{array}$ & $\frac{1}{2}$ \\
\hline $\begin{array}{l}26 \\
27 \\
25 \\
\end{array}$ & 0.99 & 0.12 & 4.00 & 10 & $\begin{array}{r}327 \\
323 \\
319 \\
\end{array}$ & 12.5 & $\begin{array}{c}1 \\
3 \\
30 \\
\end{array}$ & $\begin{array}{l}6.0 \\
4.9 \\
4.3 \\
\end{array}$ & $\begin{array}{l}1.41 \\
1.41 \\
1.41 \\
\end{array}$ & $\begin{array}{l}1 \\
1 \\
1 \\
\end{array}$ \\
\hline $\begin{array}{l}29 \\
30 \\
\end{array}$ & 0.99 & 0.12 & $\begin{array}{l}2.50 \\
5.50 \\
\end{array}$ & 10 & $\begin{array}{l}337 \\
348 \\
\end{array}$ & 12.5 & 10 & $\begin{array}{l}4.3 \\
4.6 \\
\end{array}$ & $\begin{array}{l}1.02 \\
1.82\end{array}$ & $\begin{array}{l}3 \\
1 \\
1\end{array}$ \\
\hline $\begin{array}{r}31 \\
32 \\
33\end{array}$ & 0.99 & $\begin{array}{l}0.24 \\
0.12 \\
0.06 \\
\end{array}$ & 4.00 & 10 & $\begin{array}{l}128 \\
128 \\
128 \\
\end{array}$ & 12.5 & 10 & $\begin{array}{l}5.4 \\
4.4 \\
3.5 \\
\end{array}$ & $\begin{array}{l}1.53 \\
1.21 \\
1.05 \\
\end{array}$ & $\begin{array}{l}1 \\
\frac{1}{2} \\
2 \\
\end{array}$ \\
\hline
\end{tabular}

フーチング部を固定し, 最大容量士50tのアクチュエー 夕を用いて供試体頭部に鉛直方向の正負交番荷重を載荷 した. 軸力を載荷する場合には, 頭部にロードセル, フー チング部に油圧ジャッキを配し, PC 鋼棒 4 本によって, 供試体に取り付けた。なお，供試体の頭部が荷重によっ て変位しても軸力が頭部より正しく水平方向に作用する （実際の構造物に対応させれば，頭部より鉛直下方に作 用する）という条件を満足するように，載荷用とは別の アクチュエータをフーチング部に鉛直方向に配し，これ によって頭部の鈶直変位量に等しく油圧ジャッキを上下 させる方法を採用した。

載荷にあたっては，まず，ヤング係数比 $n$ を 15 とお いた弾性計算により, 引張鉄筋がその実降伏点に達する 荷重を求めておき，この荷重に達するまで荷重制御に よって載荷して,このときの頭部の鉛直変位を計測した. この鉛直変位をその供試体の降伏変位とし, 以後は, 変

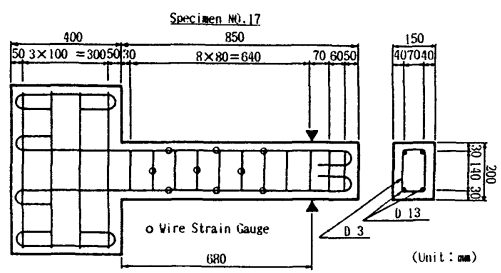

図一1 供試体の形状寸法

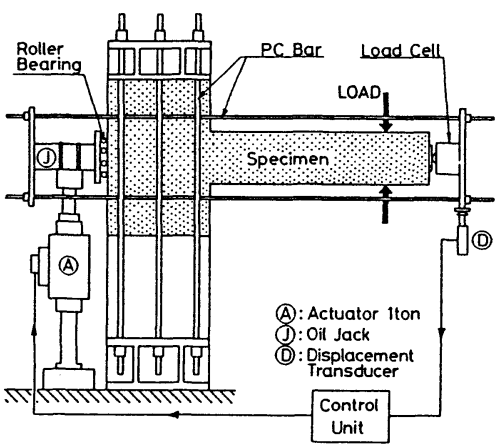

図-2 載荷装置および供試体の固定方法

表一2 用いた鉄筋の機械的性質

\begin{tabular}{|c|c|c|c|c|c|}
\hline \multicolumn{2}{|l|}{ Type } & $\begin{array}{l}\text { ヤング率 } \\
\left(\text { ton } / \mathrm{cm}^{2}\right)\end{array}$ & $\left(\begin{array}{c}\text { 降状点 } \\
\mathrm{kg} / \mathrm{cm}^{2}\end{array}\right)$ & $\begin{array}{c}\text { 降状ひずみ } \\
(\mu)\end{array}$ & $\begin{array}{l}\text { 引張強さ } \\
\left(\mathrm{kg} / \mathrm{cm}^{2}\right)\end{array}$ \\
\hline \multicolumn{2}{|c|}{ SD30.010 } & 1500 & 3650 & 2440 & 5380 \\
\hline \multirow{3}{*}{ S030.013 } & A & 1600 & 3960 & 2480 & 5470 \\
\hline & B & 1630 & 3800 & 2330 & - \\
\hline & C & 1830 & 3840 & 2100 & $\longrightarrow$ \\
\hline \multicolumn{2}{|c|}{ SD30.016 } & 1710 & 3580 & 2090 & 5910 \\
\hline \multirow{3}{*}{ S030,03 } & A & 1350 & 2740 & 2030 & 5690 \\
\hline & B & 1450 & 2400 & 1650 & 4160 \\
\hline & C & 1450 & 2540 & 1750 & - \\
\hline
\end{tabular}


位制御によって,この整数倍を片振幅として所定回の正 負繰返し載荷を行った. 上記のようにして求めた降伏変 位は, 大部分の供試体において, 引張鉄筋のひずみが降 伏ひずみに達する直前の変位であった．ごく一部の供試 体においては，上記の荷重に達する直前に引張鉄筋が降 伏した.この場合においては, 引張鉄筋が実際に降伏し たときの変位を降伏変位とした．計算をもとにして求め た降伏変位とひずみ計測をもとにした降伏変位の差はき わめて小さく, 実際上問題となることはなかった。

載荷中, 供試体頭部の鉛直変位, 荷重, フーチングか らの主鉄筋の引き抜けおよび鉄筋のひずみを通常のひず みゲージ式変換器あるいはひずみゲージそのものを用い て測定するとともに，ひずみゲージ式間隙計を供試体側 面に最多で 30 個配置して, 供試体各部の相対的変位量 を詳細に測定した7)。相対的変位量を測定したのは，測 定結果を用いて，供試体の変形状況を解析しようとした ためである.

\section{3. 正負交番荷重下の鉄筋コンクリート部材の ひびわれ・変形性状と変位分解の靶性率定 量化への適用の可能性}

\section{（1）ひびわれ状況}

実験に用いた供試体は，一部を除いて，引張鉄筋降伏 後に斜めひびわれが発生し, 最終的には斜め引張破壊あ るいはせん断圧縮破壊を生じて耐力を失った．斜めひび われを発生してから耐力を失うに至る間のひびわれの進 展状況は，以下のようである．まず降伏変位（以下 $\delta_{y}$ と略記する）程度の変位段階までは，曲げひびわれのみ が発生していた。この段階では，ある程度の大きな曲げ ひびわれは，フーチング部との取り付け部分（以下，固 定端断面という）を始めとして, 正負交番載荷を受ける ことにより断面を貫通するに至っていた．その後， $2 \delta_{y}$ 以上の変形時に至り，すでに発生していた曲げひびわれ を初期ひびわれとして, 徐々に斜めひびわれが発生し， 交番荷重によって，両方向から伸びてきた斜めひびわれ がX字状をなすようになった．以後のひびわれの発展状 況は, 図一3に示すように,3つのパターンに分類された。 すなわち，X字状斜めひびわれが 1 組のみでそこに破 壊が集中するパターン (パターン 1 )，2 組，3 組と多く

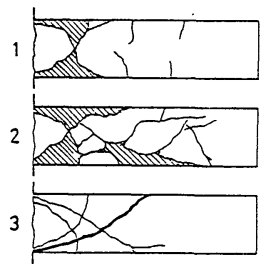

図一3供試体のひびわれパターン
のX字状ひびわれが発生して, かぶりコンクリートの剝 落などの損傷が広範囲に生ずるパターン (パターン 2$)$ および何組かのX字状ひびわれは発生するが，このうち の 1 組のX字状ひびわれのみが開いて破壊が進行し，か ぶりコンクリートがほとんど剝落せずに終局に至るパ ターン (パターン 3 ) である. おのおのの供試体におけ る破壊パターンは，表一1に示してある.この表より, 破壊パターンは作用するせん断力とせん断耐力の大小関 係によって相違し，相対的に作用せん断力が大きいもの ほよ゙パターン 1 からパターン 3 へ変化することがわか る.

\section{（2）塑性変形能の指標}

鉄筋コンクリート部材の塑性変形能を定量的に表わす 指標として, 本研究では, 勒性率すなわち, 降伏変位に 対する終局変位の比を採用した。これは，片持ちばり形 式の供試体の場合, 䩚性率が最も直接的だからである。 勒性率を求める場合，降伏変位は2.（2）に述べたよう にして定めることができるが，終局変位はこれをどのよ うに定義するかが問題となる，著者らは，すでに，正負 交番荷重を受ける鉄筋コンクリート部材の終局変位に関 して，外見上，著しいせん断ひびわれの発生その他の損 傷か認められるとともに耐力（荷重）が急激に低下し始 めるときをその部材の終局とするのが適当であるとの観 点から, 静的試験による場合, これを満足するものとし て「荷重-変位包絡線において, 荷重が降伏荷重を下回 らない限界変位」を終局変位と定義するのが適当である ことを公表している ${ }^{6)}$. 本研究においても, 最初, この 定義に従って検討を進めたが，実験結果の中には，降伏 変位をわずかに越える変位において降伏荷重以下の荷重 となったものの，それ以上の変位段階においても，なお 崩壊に至ることなくその荷重を維持したことを示すもの があった。このような場合には前述のように定義した終 局変位が, 部材が外見上崩壊とみなせる変位を大きく下 回ることになり，不合理であるので，このような場合も 包含して前述の終局状態の基準を満足する定義について 検討した。この結果，「最大荷重の $80 \%$ を下回らない限 界変位」とするのが適当であるとの結論を得たので，以 下これによって終局変位を定め，勒性率を計算した。な お，荷重-変位包絡線が上記のような特別の場合を除き， この定義による終局変位と, 前述の定義による終局変位 はほとんど同じ値となった。

\section{（3）変位の分解}

部材の変形性状について検討し, 塑性変形能を頭部の 変位によって表わすことの是非の解明に資するため, 以 下に述べるようにして，供試体頭部の水平変位を種々の 変位成分に分解した．すなわち，まず，主鉄筋の引き抜 け量の測定結果を用いて供試体頭部の全水平変位量 $\delta$ 
を主鉄筋の引き抜けによる変位 $\delta_{4}$ と脚柱部分の変位 $\delta_{0}$ に分解した. ついで, 供試体各部の相対的変形量の測定 結果を用いて $\delta_{0}$ を斜めひびわれを伴って著しく損傷し た部分の変形 $\delta_{2}$, 曲げひびわれのみの損傷が著しくな い部分の変形 $\delta_{1}$ および固定端断面のずれ変形 $\delta_{3}$ に分解 した. また，同じく $\delta_{0}$ を曲げ変形 $\delta_{s}$, せん断変形 $\delta_{s}$ お よび $\delta_{3}$ に分解した.ここでいう曲げ変形とは, 部材に 変位角を生じさせるような変形, せん断変形とはひびわ れ間のずれ変形も含んだ，変位角を生じさせないような 変形, という意味である.

（4）変位分解の結果およびその勒性率定量化への適 用の可能性

（３）に述べた各種の変位成分と全変位 $\delta$ との関係の 一例を図一 4 に示す.この図に示されているように, 実 験したすべての供試体において， $\delta_{3}$ が全変形に占める 割合は小さく, 終局時に至っても急増することはなかっ た。 $\delta_{3}$ について着目した研究は今までになかったが, この結果より， $\delta_{3}$ は部材の終局状態には大きな影響は 及ぼさないと判断される。.また， $\delta_{4}$ は本来的に部材の 終局状態には無関係である. よって, 以後は $\delta_{1}$ と $\delta_{2}$ ま たは $\delta_{f}$ と $\delta_{s}$ に着目した。

$\delta_{0}$ のうち部材の終局状態を支配する $\delta_{2}$ に着目し, 塑 性変形能を定量化しようとする試みはすでにいくつかな されている(4) -6). これは $\delta_{2}$ についての勒性率と耐力比 との間におおむ稙線関係が存在することに基づくもの である.この試みは原理的には合理的であると考えられ るが, 必ずしも成功しているとはいいがたい. 著者らは, この理由として, 上記の試みでは $\delta_{2}$ を生ずる部分の長 さ $L_{2}$ を一定と仮定しているが，これが正しくないこと を指摘するとともに， $L_{2}$ は鞀性率と同じ数多くの要因 によって影響を受け，耐力比とおおむね直線関係にある こと，および $L_{2}$ を合理的に定めれば，この方法による 靱性率算定の精度を向上させ得ることが期待できること をも指摘している ${ }^{6)}$. ここで, 本実験の結果より $L_{2}$ と 耐力比との直線式を定め, これを用いて上記の方法で靶 性率を算定した。この結果, 期待に反して靶性率算定の

精度はほとんど向上しないことが示された.この理由と して， $L_{2}$ が耐力比と直線関係にあるとの仮定が単純に 過ぎることが考えられる.すなわち，表一1 および図一 3 から予測されるように， $L_{2}$ はきわめて多くの要因に よって影響を受けるのであって，これを耐力比というよ うに包括的に扱うことはできないと考えられるのであ る.したがって， $\delta_{2}$ と $L_{2}$ とによって靶性率を定量化し ようという試みは，これを成功に導くのは容易でないと いえる.

次に, 全く新しい試みとして， $\delta_{f}$ と $\delta_{s}$ の変化状況を 調べることによって，部材の終局状態を支配する変位状 態を明らかにし，これによって靶性率を定量化すること を検討した．図一5は，この検討の一例として， $\sigma_{0}$ のみ を変化させた供試体における $\delta_{f}$ と $\delta_{s}$ の変化の状況を示 すものである.これによれば， $\delta_{s}$ は $\sigma_{0}$ の大小にかかわ らず, 変位の増大に伴って増加するが, $\delta_{f}$ の挙動は, $\sigma_{0}$ の大小によって大きく異なり， $\sigma_{0}$ が小さい供試体で は $\delta_{f}$ が減少し， $\sigma_{0}$ が大きい供試体では逆に急増したこ とがわかる. $\delta_{s}$ が変位の増大に伴って増加する現象は 図－5の場合以外でもすべての供試体で認められたか ら，これを定量化すれば鞀性率を定量化できると考えら れた。しかし，部材の終局状態は必ず $\delta_{s}$ によって支配 されるわけでなく， $\delta_{f}$ によって支配される場合もある ことが示された。それで， $\delta_{f}$ あいは $\delta_{s}$ を利用して䩲 性率を定量化するためには， $\delta_{f}$ と $\delta_{s}$ のいずれが終局を 支配するかをひびわれパターンあるいは要因の組合せに よって特定することが必要となるのである.しかし，本 実験の範囲内では，特別な関係を見出すことができな かった. したがって,この方法で部材の変形性能を評価 することは困難であると判断せざるを得ない.

部材の変形性状を詳細に検討して, 終局状態を支配す る成分を抽出し，これによって塑性変形能を定量化しよ うという考えは，現象を忠実に捉えようとするもので， 原理的には有望であると考えられた。.しかし，以上で述 ベたごとく，終局状態を支配する変位成分はきわめて多 くの要因によって複雑な影響を受けるため，この方法で 精度のよい塑性変形能算定式を得るのは, 多くを期待で

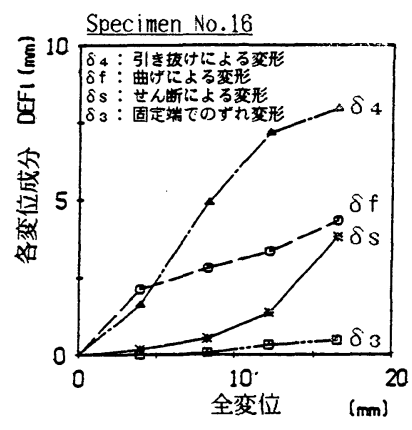

図-4 全水平变位と各変位成分との関係の一例

\begin{abstract}
四全水平变位と各变位成分との閶侻の一湖
\end{abstract}

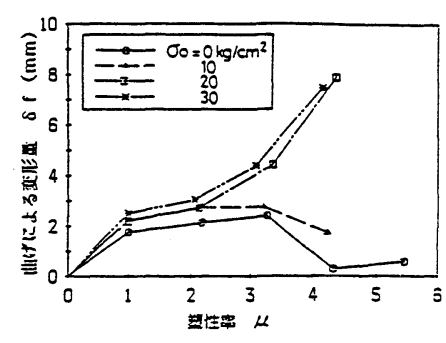

(1) 曲げ変形

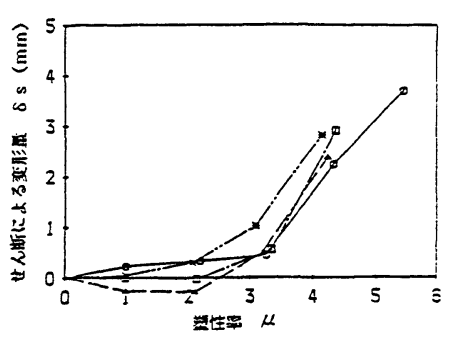

(2) 世ん断変形
図一5 $\boldsymbol{\delta}_{f}$ と $\delta_{s}$ の変化の一例（ $\sigma_{0}$ を変化させた場合） 
きないことが明らかになった。したがって，原理的には 疑問点が多いが，片持ちばり形式の場合における頭部の 変位のように，変位を包括的に取り扱わざるを得ないよ 判断される.

\section{4. 鉄筋コンクリート部材の鞋性率に及ぼす諸 要因の影響およびその定式化}

鉄筋コンクリート部材の䩚性率に及ぼす諸要因の影響 を耐力比によって総括的に表わすことの是非を検討し， 必要なら新たな方法を提案することを目的として，上に 述べた実験の結果を用いて，採用した各要因ごとに，こ れらの変化と勒性率の変化の関係について検討を加え た.この結果, 結論を先に述べれば, 耐力比という形で 諸要因の影響を包括するのは無理があり，各要因の影響 を逐一定量化する必要があることが示されたのである. それで，以下，各要因ごとに靱性率に及ぼす影響を定性 的に論ずるとともに，これを定式化した結果を述べるこ ととする，定式化にあたっては，本実験の結果のほかに 太田の実験結果 ${ }^{8)}$ および檜貝らの実験結果 ${ }^{3)}$ を併せて用 いた。

\section{（1）引張鉄筋比 $\boldsymbol{p}_{t}$ の影響}

他の要因を一定に保ち， $p_{t}$ のみを変化させた実験結 果より， $p_{t}$ が大なものほど, 勒性率が小さいことが示 された． $p_{t}$ が大となれば，曲げ耐力およびせん断耐力 のいずれも増大するが，曲げ耐力の増大の方がはるかに 大きく，作用せん断力は曲げ耐力に比例して大きくなる から，せん断耐力が相対的に低下する．このため， $p_{t}$ が大のほど靶性率が低下するのである.

図一6は， $p_{t}$ 之靶性率との関係を定式化するために描 いたもので，両者の関係を， $p_{t}=1 \%$ のときの䩲性率に 対する任意の $p_{t}$ のときの勒性率の比 $\mu_{r u t}$ を用いて示し たものである.これによれば, $p_{t} \leqq 1.0 \%$ の領域で $\mu_{\text {rut }}$ が急増することが明瞭に認められる． $p_{t}$ が減少すれば 靱性率が増大することは，定性的には，従来の耐力比之 䩚性率との関係に合致するものであるが，図一6にみら

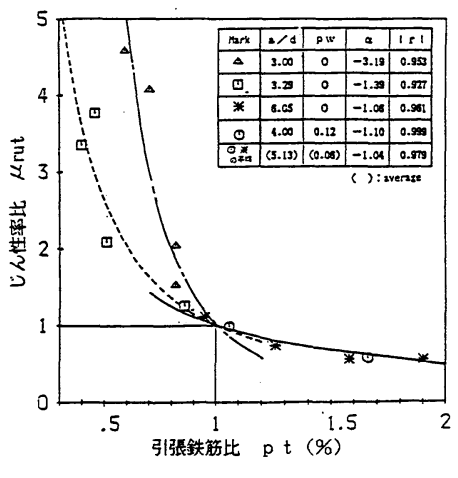

図一6 $\boldsymbol{p}_{t}$ と靶性率比との関係
れるような急激な増加は従来の算定式では組み込まれて いるか否かは疑問である．図一6より，

$$
\beta_{t}=\mu_{r u t}-1=\left(p_{t}\right)^{\alpha}-1
$$

ここに， $\beta_{t}$ は勒性率に及ぼす $p_{t}$ の影響を表わす係数で, $p_{t}$ が 1.0 のとき $\beta_{t}$ は 0 である.また， $\alpha$ は， $p_{w}$ および $a / d$ による定数である. $p_{w}$ および $a / d$ が変わると $\alpha$ がどのように変化するかを最小二乗法によって検討した 結果は，図一6に併記したようであって， $p_{w}$ の影響は 小さく無視してよいこと， $a / d \geqq 4.0$ のとき， $\alpha$ はほと んど一定であるが， $a / d$ が減少すると双曲線的に増大 すること等が判明した，この結果に基づき，

$$
\alpha=-0.146 /(a / d-2.93)-0.978
$$

を得た。ただし，この式の適用範囲は，用いた実験結果 が $a / d \geqq 3.0$ ののであることを考慮すれば, $a / d \geqq 3.0$ とするのが妥当である. 一般の土木構造物に おける $a / d$ はおおむねこの範囲にあるから，この適用 範囲の制限は大きな問題とはならないものと思われる.

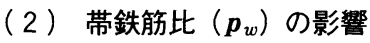

他の条件が同じで $p_{w}$ が増せば，靶性率は当然増加す る.これを定量的に検討するために, $p_{t}$ の場合と同様に， $p_{w}=0.1 \%$ のときの靶性率に対する比 $\left(\mu_{r u t}\right)$ を求めて 検討した。この結果は図一7のようであって，両者の関 係はほぼ線形であることが認められた。すなわち，

$$
\beta_{w}=\mu_{r u t}-1=2.70\left(p_{w}-0.1\right)
$$

ここに, $\beta_{w}$ は $p_{w}$ の効果を表わす係数である. $\beta_{w}-p_{w}$ 関 係には $\sigma_{0}, p_{t}, a / d$ などが影響を及ぼすが，これらの うち， $\sigma_{0}$ と $p_{t}$ は，図一7にみられるように，その影響 が小さいため無視した。また， $a / d$ に関しては，これ が 4.0 の場合のデータしか用いなかったので，これが $\mu_{u t r}-p_{w}$ あるいは $\beta_{w}-p_{w}$ 関係に及ぼす影響は検討できて いない.

\section{（3） $\boldsymbol{a} / \boldsymbol{d}$ の影響}

他の条件を一定とし， $a / d$ のを $3 \sim 5$ に変えた場合 の荷重変位履歴曲線の包絡線 (以下, 単に包絡線という) . より， $a / d$ が小さいほど䩚性率が小さくなることが示

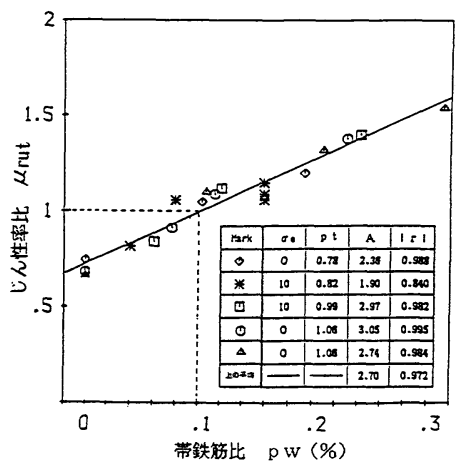

图-7 $\boldsymbol{p}_{w}$ と靶性率比との関係 
された.

一般に $a / d$ が小さいほどせん断耐力は大きくなる. それにもかかわらず上記のような結果が得られたのは， 実験した供試体のような場合においては，固定端断面に おける曲げモーメントが等しい場合， $a / d$ が小さいほ ビ作用するせん断力が大きくなり，これがせん断耐力の 増加を上回るからであると考えられる．このことは，せ ん断耐力に関する既往の研究成果で認められている事 実，すなわち， $a / d$ が 3 以上の範囲では， $a / d$ が小さ いほど耐力比が小さくなるという事実と一致している.

勒性率に及ぼす $a / d$ の影響を定式化するために, 上 記の結果に軸圧縮応力 $\sigma_{0}$ を $0 \mathrm{~kg} / \mathrm{cm}^{2}$ および $10 \mathrm{~kg} / \mathrm{cm}^{2}$ とした場合の結果より， $a / d$ と $a / d=4$ のときを基準 として計算した $\mu_{r u t}$ との関係を求めた。この結果は図 -8に示すようである.これによれば， $\mu_{r u t}$ は $a / d$ と 直線関係を保って増加するが, 増加の程度は $\sigma_{0}$ の大き さによって異なり， $\sigma_{0}$ が大きいほど增加の程度が小さ

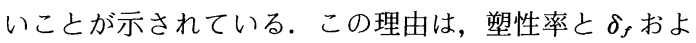
び $\delta_{s}$ との関係，ひびわれ状況などを詳細に検討した結 果, 以下のようであることが判明した．すなわち， $a / d$ が小さい場合， $\sigma_{0}$ が作用しなければ，斜めひびわれ間 のせん断伝達能力が低下して破壊に至るが， $\sigma_{0}$ が作用 するとこの能力が増し, 靶性率が増す.一方, $a / d$ が 大きい場合， $\sigma_{0}$ が作用しなければ，固定端付近のX字 状ひびわれの塑性ヒンジ的な回転が変形の大きな割合を 占めるが， $\sigma_{0}$ が作用する場合は，軸力による圧縮力の ため, 圧縮鉄筋の座屈, かぶりコンクリートの剝落など が助長されて, 勒性率が大きくなり得ない。結局, $\sigma_{0}$ が作用すると, $a / d$ の変化に伴う鞀性率の変化が小さ くなるのである.このような事実は, 耐力比によっては 表わし得ないのであって, 鞁性率を耐力比によって表わ すことが適当とはいえない顕著な例であるといえる.

上記の実験事実より， $\sigma_{0}$ は $\mu_{r u t}$ と $a / d$ の直線式にお いてその勾配に影響を及ぼすといえるが，定量的には， これを十分に明らかにできなかった。それで，やむを得

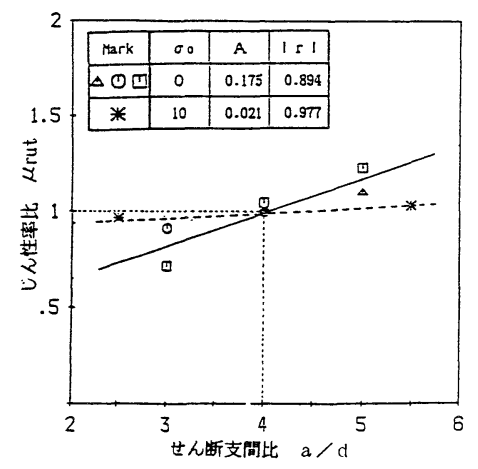

図一8 $\quad \boldsymbol{a} / \boldsymbol{d}$ と勒性率比との関係
ず， $\sigma_{0}$ の影響は直線の勾配と線形関係を保つと仮定し

て,これを組み込んだ. 求められた関係式は,

$$
\beta_{a}=\mu_{r u t}-1=A(a / d-4) \cdots
$$

ここに

$$
\begin{array}{ll}
A=-0.0153 \sigma_{0}+0.175 & \left(\sigma_{0} \leqq 11.4 \text { のとき }\right) \cdots(5) \\
A=0 & \left(\sigma_{0}>11.4 \text { のとき }\right) \cdots(6)
\end{array}
$$

式（5）では， $\sigma_{0}$ の影響を線形とした関係上， $\sigma_{0}>11.4$ のとき $A$ が負となる。これは実際の現象とは合致しな いので,このときには， $A=0$ としたのである. 上式を 求めるにあたり, $p_{w}=0.12 \%$ の実験結果しか用い得な かったので, $p_{w}$ と $a / d$ との交互作用は考慮されていな い.この点は, $\sigma_{0}$ の影響と合わせて, 今後の検討課題 である。

\section{（4） コンクリート強度 $\left(\boldsymbol{f}_{c}^{\prime}\right)$ の影響}

他の条件を一定とし，コンクリート強度のみを 128 $565 \mathrm{~kg} / \mathrm{cm}^{2}$ に変化させた場合の包絡線をもとに，コン クリート強度が $300 \mathrm{~kg} / \mathrm{cm}^{2}$ の場合を基準にとって, $\mu_{r u t}$ と $f_{c}^{\prime}$ との関係を図示した. 図一9はこの結果を示 すもので，帯鉄筋が配置されている場合には， $f_{c}^{\prime}$ は勒 性率にほとんど影響を及ぼさないことが示された。この 理由は以下のようであると考えられる．すなわち， $f_{c}^{\prime}$ の相違は，斜めひびわれの発生時期および範囲に影響を 及ぼし， $f_{c}^{\prime}$ が低いほど時期が早く，範囲が広くなる. しかし, 帯鉄筋が配置されていると, 作用せん断力の相 当部分が带鉄筋によって受け持たれるため， $f_{c}^{\prime}$ の上記 のような影響は少なくなり，靶性率に及ぼす影響も小さ くなるのである. 一方，帯鉄筋が配置されていない場合 には，斜めひびわれの発生は，ただちに，耐力低下をも たらすから， $f_{c}^{\prime}$ は靶性率に影響を及ぼすのであり，こ のことは，図一9にも示されている，すなわち， $f_{c}^{\prime} に$ 関しては，帯鉄筋の有無で䩲性率の評価式を変える必要 があり，これも耐力比で包括的に評価することの 1 つの 限界を示している. 図一9の結果より，

$$
\beta_{c}=\mu_{r u t}-1=A\left(f_{c}^{\prime}-300\right)
$$

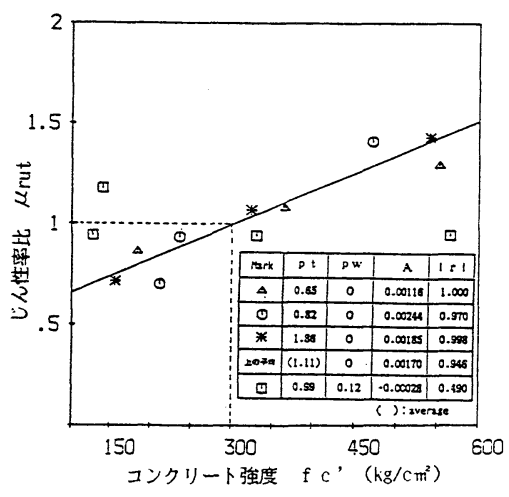

図-9 $f_{c}^{\prime}$ と鞋性率比との関係 
ここに,

$$
\begin{array}{ll}
A=0.00170 & \left(p_{w}=0 \% \text { のとき }\right) \\
A=0 & \left(p_{w} \neq 0 \% \text { のとき }\right)
\end{array}
$$

\section{（5）軸方向応力度（ $\sigma_{0}$ ) の影響}

$\sigma_{0}$ のみを 0 30 kg/ $\mathrm{cm}^{2}$ に変えた実験結果より，他の 条件が一定なら，これが大きいほど，靶性率が小さいこ とが示された。 そこで， $\sigma_{0}=10 \mathrm{~kg} / \mathrm{cm}^{2}$ のときを基準に とって $\mu_{r u t}$ と $\sigma_{0}$ との関係を図示した (図一10).これ より,

$$
\beta_{N}=\mu_{r u t}-1=2.15\left(\sigma_{0}+10\right)^{-0.260}-1 \text {. }
$$

式 $(10)$ を導くのに用いたデータが $a / d=4.5, p_{t}=1.0$ $\%, p_{w}=0.1 \%$ ののだけであったことより, 式の精度 が疑問であったが，島津の成果 ${ }^{2}$ 亡比較した結果，ほ之 んビ差が認められなかった。したがって, 式 (10)の精 度には大きな問題はないものと考えられる。

\section{（6）繰返し回数（n）の影響}

他の条件を一定とし， $n$ のみを 1 ３0回に変化させた 場合の包絡線より, $n$ が多いほど終局変位が小さくなり, この傾向は $n$ が小さい範囲において著しいことが示さ れた。これの理由は， $n$ が大きくなるほよ゙， $\delta_{s}$ が増加 し始める変位が小さいことより， $n$ が増大すると，斜め ひびわれの面でずれ変形が生じる回数が増し，ひびわれ 面が摩耗してこの部分で受け持たれるせん断力が減少す るためと推定される.これを定量化するため, 絽返し数 $n=10$ のときを基準として,$\mu_{\text {rut }}$ と $n$ との関係を図化 した.この結果は図一11に示すようである.この図より, 両者の関係は，おおむね指数関数で表現できるものと考 えられたので， $\mu_{r u t}=a(n)^{\alpha}$ と仮定し， $a$ および $\alpha$ を 最小二乗法によって定めた。この結果，下式を得た。

$$
\beta_{n}=1.26(n)^{-0.0990}-1 \text {. }
$$

なお，実際の地震時には，実験におけるように，降伏変 位の整数倍の変位が繰返し載荷されるような状態は生じ 得ない。したがって, 塑性変形能を算定する式に繰返し 数 $n$ を変数として考慮することは, 実際上はあまり意 味がない。しかし, 繰返し数が増せば, 塑性変形能が低

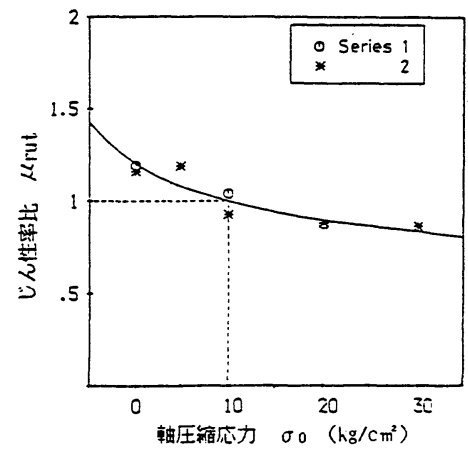

图一10 $\quad \sigma_{0}$ と靶性率比との関係
下することは確かであるから，実験において， $n>10$ の 範囲では $\beta_{n}$ がほとんど変化しなかったことを考慮して， 設計には， $n=10$ としておくのがよいと考えられる.

上記のほかに，粗骨材の最大寸法の影響を検討した． しかし，検討に用いたデータが比較的小型の供試体によ るものであったことを考慮すると，最大寸法の影響は， 次章で述べるような形で取り扱うのがよいと考えられた ので，他の要因と同様の定式化は行わないこととした.

\section{5. 塑性変形能算定式の提案}

これまでに述べた各種要因が塑性変形能に及ぼす影響 をまとめ, 各種の要因の影響を表わす係数を合計する形 として，塑性変形能算定式を提案する，すなわち，

$$
\mu_{u}=\beta_{0}\left(1+\beta_{t}+\beta_{w}+\beta_{c}+\beta_{N}+\beta_{a}+\beta_{n}\right) \cdots
$$

この式は, 形式上, 各種要因の主効果のみを取り上げ, 交互作用は無視した形となっている。しかし，前述した とおり，おのおのの係数 $\beta$ はそれ自体他の要因との交 互作用を含んでいるので，このような形を採用しても， 交互作用を全く無視したことにはなっていないのであ る.

上式中， $\beta_{0}$ は括弧内で考慮しなかった要因の影響を 表わすために導入したものである． $\beta_{0}$ で考慮すべき要 因としては，上式では含まれていない要因，すなわち， 粗骨材の最大寸法 $G_{\max }$ あるいはこれと密接な関係があ ると思われる部材の有効高さ $d$ が主なものであろう. これらの影響を検討するため，式（12）に鞄性率の実験 値とそれぞれの要因による $\beta_{t} \sim \beta_{n}$ を代入して $\beta_{0}$ を計算 し，これと $d$ あるいは $G_{\max }$ との関係を図化した， $d$ の

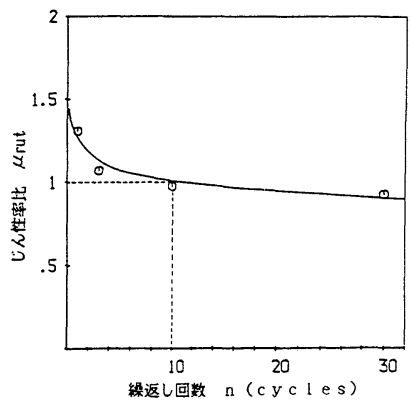

图一11 $n$ と鞄性率比との関係

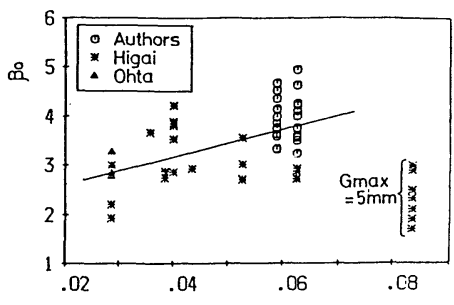

图一12 $\beta_{0}$ と $1 / d$ との関係 
場合についての結果は，図ー12 のようである. 図-12 より, $\beta_{0}$ と $1 / d$ との関係は, $G_{\max }=5 \mathrm{~mm}$ の場合を除 けぱ，おおむね線形であることがわかる，そこで，最小 二乗法によって両者の関係を求めた結果, 次式を得た.

$$
\beta_{0}=28.4 \times 1 / d+2.03 \text {. }
$$

$G_{\max }=5 \mathrm{~mm}$ の場合は, $d=12 \mathrm{~cm}$ の供試体だけでデー 夕数が少ないため, 特に関係式を求めることはせず, $\beta_{0}$ $=2.33$ の一定値とした. 実際の場合に $G_{\max }=5 \mathrm{~mm}$ と することはないので,これは大きな問題にはならないと 思われる. $\beta_{0}$ と $G_{\max }$ の関係については, $d$ と $G_{\max }$ と の相互作用を考慮して, $\beta_{0} /(28.4 / d+2.03)$ と $G_{\max }$ と の関係を検討した. その結果, 両者の相関係数は $r=$ 0.277 となり, 密接な関係があるという結論は得られな かった．このことは， $G_{\max }$ の影響は， $d$ によってすで に考慮されているということを意味する。すすなわち， $G_{\max }$ の影響は式に入れる必要はないといえるのである. なお， $\beta_{0}$ は $d$ あるいは $G_{\max }$ に関するデー夕が蓄積され れば，ほかの要因と同様, 式（10）の括弧内に入れる取 扱いも可能であると考えられる.

以上の結果を取りまとめると，鉄筋コンクリート部材 の䩲性率算定式として，次式が得られる.

$$
\begin{array}{rlrl}
\mu_{u} & =\beta_{0}\left(1+\beta_{t}+\beta_{w}+\beta_{c}+\beta_{N}+\beta_{a}+\beta_{n}\right) \cdots \\
\beta_{0} & =28.4 / d+2.03 & & \left(G_{\max }>5 \mathrm{~mm}\right) . \\
& =2.33 & \left(G_{\max }=5 \mathrm{~mm}\right) .
\end{array}
$$

$$
\beta_{t}=p_{t}^{\alpha}-1
$$

$\alpha=(-0.146 /(a / d-2.93)-0.978) \quad(a / d \geqq 3.0)$

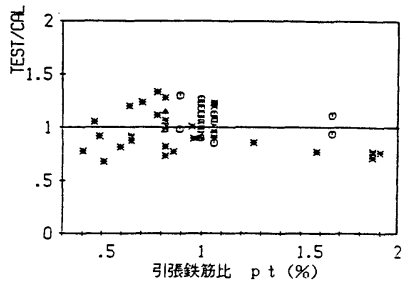

図-13 靬性率の計算值に対する実験值の比と $\boldsymbol{p}_{t}$ との関係

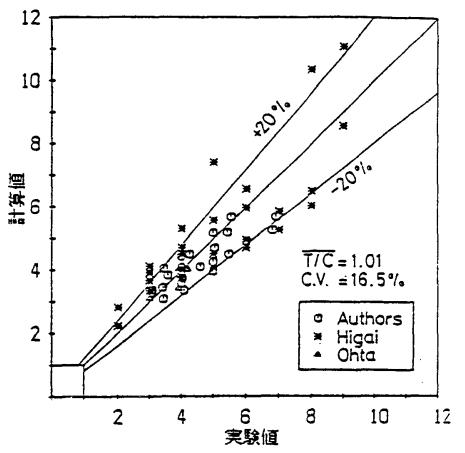

図-14 提案式の精度の検討

$$
\begin{aligned}
& \beta_{w}=2.70\left(p_{w}-0.1\right) \\
& \beta_{a}=\left(0.0153 \sigma_{0}+0.175\right)(a / d-4.0) \\
& \left(\sigma_{0} \leqq 11.4 \mathrm{~kg} / \mathrm{cm}^{2}\right) \\
& =0 \\
& \left(\sigma_{0}>11.4 \mathrm{~kg} / \mathrm{cm}^{2}\right) \\
& \left(p_{w} \neq 0 \%\right)
\end{aligned}
$$

ここに, $d$ は $\mathrm{cm}$ 単位, $f_{\mathrm{c}}^{\prime}$ は $\mathrm{kg} / \mathrm{cm}^{2}$ 単位, $p_{t}, p_{w}$ は\% で表わしたものである.

\section{6. 提案した靶性率算定式の評価}

提案した鞁性率算定式の精度を以下のようにして, 評 価した．評価にあたっては，まず，靸性率の計算値に対 する実験值の比と各要因の関係について検討を加えた。 図一13 は，この例として， $p_{t}$ の場合について示すもの である、これによれば，計算值に対する実験値の比は， $0.7 \sim 1.3$ であること, また, この比と $p_{t}$ との間には特 別な関係は存在しないこと, 等がわかる.すなおち,こ れにより, 評価式は, 靱性率に及ぼす $p_{t}$ の影響を的確 に考慮できていると判断できる. $p_{t}$ 以外の要因につい ても同様の検討を行った.この結果, 提案した評価式は, 靶性率に及ぼす諸要因の影響を, $p_{w}=0 \%$ の場合を例外 として, 適切に考慮できていることが確かめられた. $p_{w}=0 \%$ の場合では, 計算値と実験値の比の変動が若干 大きく，その影響を他の要因と同程度に考慮できている とはいいがたかった。これは，前章でも述べたように， $p_{w}=0 \%$ の場合， $a / d$ との交互作用が取り入れられて

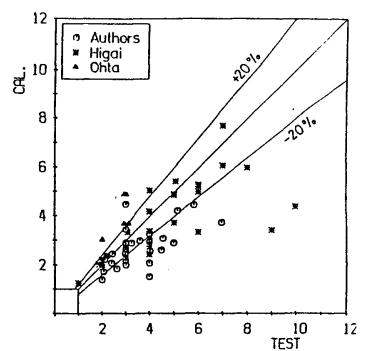

（1）檜只

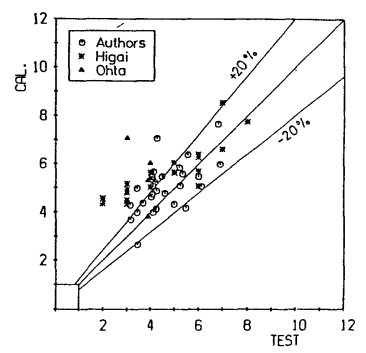

(2) 石橋

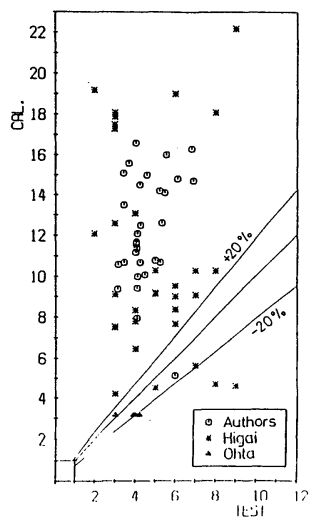

(3) 荒川

図-15 既往の提案式の精度 
いないことによると考えられる.

以上に次いで，実験によって得られた鞀性率と提案式 によって推定した鞀性率とをすべての供試体について比 較した.この結果は図一14に示すようで, ほとんどの 供試体に対して $20 \%$ 範囲内の精度で鞀性率を推定 できていること, 勒性率の大小にかかわらず, 算定の精 度はほぼ一定であること, などがわかる。 また, 䩲性率 の推定值に対する実験值の比は平均 1.01 , 変動係数 $16.5 \%$ であった. 既往の提案式を用い, 同じデー夕に ついて計算した結果は, 図一15のようであり, 本提案 式は, 推定の精度が相当に改善されていることが明瞭に 理解されよう。

以上の検討により, 提案式を導くのに用いたデータの 偏りの影響は問題がないことが明らかとなった.それで, 式の導出には全く用いていない実験データによって，提 案式の評価を行った. 用いた実験デー夕は, 建設省土木 研究所によるもの ${ }^{9}$ および尾坂らによるもの ${ }^{10)}$ である.

これらを用いたのは, 高さ $h=80 \sim 40 \mathrm{~cm}$ の比較的大型 の供試体を用いていることおよび側方鉄筋を配した供試 体を含んでいること，などによる．なお，用いたデー夕 には, 静的に載荷されたもののほか, 最大で $75 \mathrm{~cm} / \mathrm{s}$ の 載荷速度で載荷された場合の実験結果も含まれている.

図一16は，これらの実験による鞀性率の実験值と本 提案式による計算值を比較したものである.これによる 亡, 計算值は若干危険側ではあるが, 計算值とよく一致 していることがわかる. 全供試体についての, 計算值に 対する実験值の平均值は 0.91 , 変動係数は $15.7 \%$ で あって,これによっても, 計算值はほぼ妥当な結果を与 えていることがわかる.しかし，側方鉄筋がなく静的に 載荷された 3 体について着目した結果, これらの供試体 についての計算値に対する実験值の比は平均 0.83 で あって，相当に小さかったことが判明した。これらの供 試体は提案式の導出に用いた供試体と断面の大きさ以外 は同条件のものである.したがって，この結果は，本提 案式は, $d$ の大きい場合に対しては, 危険側の計算值を

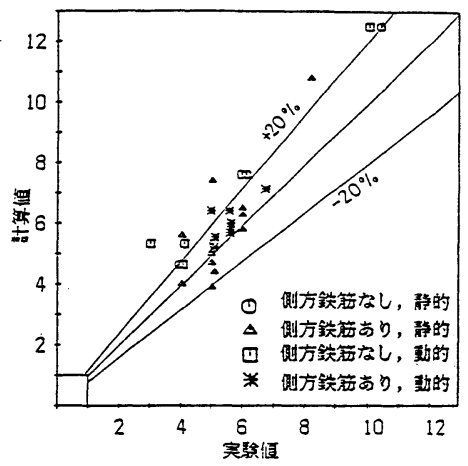

図一16 大型供試体のデータによる提案式の精度の検討
与えることを示している. また, 側方鉄筋の有り無しに 分けて計算值に対する実験值の比を求めた結果, 有りの 場合 0.95 であったのに対し，無しの場合，0.81であっ て, 提案式は側方鉄筋の影響を考慮していないにもかか わらず，有りの場合の方が実験に近い值を与えた。これ は, 本提案式は断面の大きい場合に対しては危険側の結 果を与えるが，側方鉄筋の鞀性を向上させる効果によっ て，これが軽減されたとみるのが妥当であろう.

このように，本提案式は，断面の大きい場合に対する 適用性には若干の問題があり，また，側方鉄筋の影響は 考慮できていないことが示された. しかしながら, 提案 式の導出に用いたのと条件が大幅に異なる供試体に対 し, 変動係数 $15.7 \%$ の精度で靶性率を算定できたこと は, 本提案式は, 鉄筋コンクリート部材の塑性変形能に 及ぼす各種要因の影響を，本質的にはほぼ忠実に考慮で きており，必要であれば，若干の修正を施すことによつ て, 十分実用に耐え得る塑性変形能算定式亡なるものと 考えられる.

\section{7. 結 論}

鉄筋コンクリート構造物の耐震性能を評価するにあ たって重要となる部材の塑性変形能を明確にすることを 目的として, 研究を行った. 正負交番荷重下のひびわれ 性状および変形性状に関して実験を行うとともに，部材 の塑性変形能の指標として䩚性率を採用し, 既往の実験 結果を含めて, 靶性率算定式を作成提案したのである. 研究の範囲内で, 以下のことが結論される.

（1）鉄筋コンクリート部材の塑性変形能を定量化す る方法として, 部材の変形を分解して, 終局状態を支配 するせん断ひびわれを伴う損傷が著しい部分の変形を抽 出して塑性率評価式を作成しようとする方法がある.こ れは，考え方としては優れた方法であるが，この方法に よって部材の終局変位を定量化しようとすると, 著しい 損傷を生ずる部分の変形のほかにこの部分の範囲をも求 めておく必要性が生ずる.これは, 煩雑であるうえ, 両 者がきわめて多くの要因の影響を受けるので, 精度よく これらを求めるのは非常に困難であり, したがって, こ の方法によっては精度のよい䨣性率評価式を得るのは期 待できない。

この方法に変わるべき方法として, 部材本体部分の変 形を曲げ変形とせん断変形とに分離して終局状態におい て支配的な影響をもつ変形のみを定量化する方法が考え られる.この方法につき試験した結果, 変位を曲げおよ びせん断変位に分解することは, 曲げ性状を解明するう えでは有効であるが, 終局変位を定量化するうえでは, 有効でないことが判明した，それは，各変位成分がどの ような状態に至ったときに終局に至るかは, 要因のわず 
かな変化で変わるからである．したがって，部材全体の 変位を部材の終局状態を支配するであろう変位成分を含 むいくつかの変位成分に分解して終局変位を定量化しよ うという試みには，多くを期待できないと判断される.

（2）従来，各種の要因が部材の終局状態に及ぼす影 響を曲げ耐力に対するせん断耐力の比によって包括的に 表わし，これと靱性率との関係を求めて，終局変位を定 量化する方法が採用される例が多い，この方法は，曲げ 耐力に対するせん断耐力の比が大きいものほど䩚性率が 大きく，経験上両者がおおむね直線関係に近いことに基 ゔいている．この方法で精度のよい靶性率算定式が得ら れるためには各種要因が耐力比に及ぼす影響の程度と靶 性率に及ぼすそれとがほぼ等しいことが必要である。そ れで, 部材の変形性状と各種要因との関係を詳細に検討 した結果，必ずしもこれが満足されているとはいいがた いことが示された。たとえば，引張鉄筋比が小さくなる と，勒性率は大きくなるが，その程度は耐力比から予測 されるよりはるかに大きいこと， $a / d$ の影響は軸方向 応力度の大きさによって異なることなどである．また， コンクリート強度においても，せん断耐力は带鉄筋の有 無にかかわらずコンクリート強度が増加すれば増加する が，靶性率は帯鉄筋が配置されている場合，コンクリー 卜強度にはほとんど影響を受けないことが示されてい る．これらの事実はすべて終局変位に及ぼす各種要因の 影響を耐力比によって包括的に表わすことは近似的は別 として，原理的には不適当であることを示している。し たがって，実際の現象に基づいた精度のよい䩚性率算定 式を得るためには，各種要因が終局変位に及ぼす影響を 逐一定量的に把握し，これに基づいて算定式を作成する のがよいといえる.

（3）（1）に述べた事項に従って片持ちばり供試体 の頭部の変位を目的関数に取り, 本研究における実験結 果と既往の実験結果を併せて用いて，（2）に述べた事 項に従って靭性率と各種要因の関係を逐一検討して数式 化し，これらを組み合わせて靶性率算定式を作った。こ の式は，影響要因として，引張鉄筋比，帯鉄筋比，せん 断スパン比, 軸方向応力度, コンクリート強度, 粗骨材 の最大寸法および載荷繰返し回数を考慮することができ るものである. 式の作成に用いたデー夕についてこの式 の精度の評価を行った結果，算定值に対する実験値の比
の平均値は 1.01 であり変動係数は $16.5 \%$ であって，十 分正しい值を与えるとともに, 要因がどのように変化し ても算定精度の大きな変化は認められず，満足できる精 度であることが認められた.また,式の作成に用いなかっ た比較的大型の供試体についての実験結果を用いて提案 式の精度を検討した結果，断面が大きい場合および側方 鉄筋が配置されている場合など，式の提案に用いた実験 結果の範囲を越える 2,3 の点で，若干の修正の余地が あるが，考慮した各種要因の影響は，本質的に忠実に考 慮できていることが認められた。

謝辞：なお，本研究の実施にあたり，文部省科学 研究費補助金（課題番号 60550343）を受けた。ここに 記して謝意を表わす次第である.

\section{参 考 文 献}

1）荒川 卓，ほか：鉄筋コンクリート柱の繰返し挙動と塑 性変形性能の評価, 第 5 回コンクリート工学年次講演会 論文集, 1983.

2) Shimazu, T. : On the ultimate values of deformation angle for reinforced concrete columns, Trans. of A. I. J. No. 312,1982

3）檜貝 勇，ほか：大変位の繰返しによる鉄筋コンクリー 卜部材のせん断破壊, 第 6 回コンクリート工学年次講演 会論文集, 1984 .

4）石橋忠良，ほか：鉄筋コンクリート部材のじん性率，構 造物設計資料 No. 79,1984 .

5）豊田和彦，ほか：RC 部材の終局変位定量化に関する研 究，土木学会第 39 回年次学術講演会概要集，1984.

6）豊田和彦，ほか：RC 部材の終局変位定量化に関する実 験的研究，第 7 回コンクリート工学年次講演会論文集, 1985.

7）平石, ほか：耐震壁のせん断変形と曲げ変形の算定方法, 日本建築学会大会概要集, 1982.

8）太田 実：単一式鉄筋コンクリート橋脚の耐震設計法に 関する研究，土木研究所報告 第 153 号， 1980.

9）建設省土木研究所地震防災部耐震研究室：RC 橋脚の動 的耐力に関する実験的研究，(その 1 ) 昭和 56 年度 昭 和 58 年度の検討結果, 土木研究所資料第 2232 号, 1985.

10）尾坂芳夫：ランダムな動的荷重を受ける $\mathrm{RC}$ 構造の諸特 性と耐震設計への応用に関する研究, 昭和 58 年度科学研 究費補助金研究成果報告書, 1984 .

(1986.6.25・受付) 